\title{
Быть или не быть генеральным планам крупных городов
}

\author{
Л.Я.Герцберг, ЦНИИП Минстроя России, Москва
}

Статья написана в рамках дискуссии, возникшей в результате поручения В.В. Путина правительству заменить генпланы крупных городов на стратегические планы для ускорения градостроительного обеспечения строительства. Мнения специалистов по данному вопросу разделились. Для того чтобы оценить целесообразность такого решения анализируется опыт проектирования крупных российских городов в условиях плановой экономики. Также анализируется современный опыт Англии, включая законодательную базу в области стратегического градостроительного планирования, опыт разработки стратегического Плана Большого Лондона и локального плана города Лондона. Проведённый анализ позволяет прийти к выводу о том, что крупный город должен иметь стратегический план развития. 0 н включает видение, или миссию города, набор стратегий в разных сферах жизнедеятельности города (жилищная, промышленная, инфраструктурная, экологическая и др.), определение согласованной политики их пространственной реализации, общей концепции пространственного развития города, направленных на достижение миссии города. Стратегический план крупного города должен разрабатываться на территорию города и прилегающие территории, с которыми осуществляется активная повседневная связь. Он должен иметь социальное и ресурсное обоснование, механизмы реализации, содержать показатели, по которым осуществляется мониторинг этой реализации. Основная цель этого плана - не ускорить градостроительное обеспечение строительства, а способствовать формированию успешного города: комфортного, привлекательного для инвестиций, жителей и приезжих. Наличие стратегического плана не исключает необходимость разработки генеральных планов на крупные административно-территориальные образования в рамках планируемой территории с целью детализации определённой для них стратегии. Эффективность планов зависит от применения современных технологий разработки решений и управления их реализацией, а также от того, насколько социально и экономически обосновано видение города.

Ключевые слова: генеральный план, пространственный план, миссия города, городская политика, технологии разработки, управления, реализация, ресурсное и социальное обоснование.

\section{Is There a Need for Master Plans for Large Cities}

L.Ya.Gertsberg, TSNIIP Minstroy of Russia

The article is written on the topic of discussion that arose as a result of the instructions of V.V. Putin to government to replace the general plans of large cities with strategic plans to accelerate urban planning construction. Opinions of experts on this issue are divided. In order to assess the feasibility of such a decision, the experience of designing large Russian cities in a planned economy is analyzed. The article also analyzes the current experience of England, including the legislative framework in the field of strategic urban planning, the experience of developing a strategic plan for Greater London and a local plan for the city of London. The analysis performed allows us to conclude that a large city should have a strategic development plan. It includes the Vision, or the mission of the city, a set of regulated approaches in different areas of the city's life (housing, industry, infrastructure, environment, etc.), the definition of a coordinated policy of their spatial implementation, the general concept of the spatial development of the city, aimed at achieving the city's mission. The strategic plan of a large city should be developed on the territory of the city and adjacent territories with which active daily communication is carried out. It should have a social and resource rationale, implementation mechanisms, contain indicators for which this implementation is monitored. The main goal of this plan is not to speed up the urban-planning provision of construction, but to contribute to the formation of a successful city: comfortable, attractive for investments, residents and visitors. The presence of a strategic plan does not exclude the need to develop master plans for large administrative-territorial entities within the framework of the designed facility with a view to detailing the strategy defined in the strategic plan for the development of these territories. The effectiveness of plans depends on the use of modern technologies for developing solutions and managing their implementation, as well as on how socially and economically justified the vision of the city.

Keywords: general plan, spatial plan, city mission, city policy, development technology, management, implementation, resource and social justification.

В настоящее время в развитых зарубежных странах наблюдается настоящий бум в области стратегического плани- 
рования. Многие европейские страны (Великобритания, Германия, Франция, Испания и др.) разработали или завершают разработку стратегических планов крупных городов с зонами их влияния: Большой Лондон, Париж / Иль-де-Франс, Большой Берлин и др. Видимо этот факт явился одной из причин поручения В.В. Путина правительству «представить предложения по переходу в крупных городах от генерального плана к документу, определяющему стратегические направления градостроительного развития города, основанного на стратегии социально-экономического развития и необходимости реализации государственных и муниципальных программ» [1]. Поручение было дано по итогам расширенного заседания президиума Государственного совета 22 ноября 2018 года. В этой связи в прессе развернулась дискуссия среди специалистов в пользу и против сохранения генеральных планов» [2]. Справедливости ради, следует отметить, что в соответствии с Градостроительным кодексом одной из основных задач генерального плана является систематизация и картографическое отображение всех мероприятий, планируемых в стратегиях социально-экономического развития, государственных и муниципальных программах. Так в чём же разница между существующим и предлагаемым подходами? Очевидно, что разница должна быть в содержательной части документов, управлении разработкой и реализацией плана. В период плановой экономики проблема генеральных планов состояла в низком проценте реализации проектных предложений, в большинстве своём, не превышающем 15\%. Это было вполне объяснимо: планирование осуществлялось по пятилеткам, а генеральные планы разрабатывались на срок 20-25 лет, проектировщикам самим приходилось рассчитывать на прогнозный срок объёмы строительства, используя нормативы, не имевшие ресурсного обоснования и, соответственно, они лишь частично реализовывались.

Достоинством генеральных планов являлась их ориентация на повышение качества городской среды, планировалось выводить за пределы города вредные производства, переселять население из зон санитарной вредности, сносить ветхий и аварийный фонд, увеличивать площадь озеленения и др. К сожалению, в большей своей части это не реализовывалось. Авторы Градостроительного кодекса нашли решение проблемы реализации, сводя содержание генеральных планов в значительной степени к отражению только планируемых мероприятий.

Следует также отметить, что до 2010 года генеральные планы крупных городов разрабатывались в две стадии: ТЭО - концептуальный документ, и собственно генеральный план. Объектом проектирования был крупный город и пригородная зона. От чего также по результатам корректировки Градостроительного кодекса отказались. В результате Генеральный план превратился в пассивный документ, не выполняющий в полной мере градорегулирующей функции.

Каким же должен быть современный проект определяющий стратегию крупного города, и на какую территорию он должен разрабатываться? С ростом уровня автомобилизации и развитием общественного транспорта повседневная деятельность людей все меньше замыкается в границах города. Часть жителей крупных городов предпочитает жить в пригородах с более благоприятной экологической ситуацией, иметь отдельный дом вместо квартиры. Решение проблем территориальных резервов для городского строительства, как и экологических проблем, проблем утилизации мусора, рекреации и др., также выходит за границы города. Всё это свидетельствует в пользу того, что стратегию развития крупного города надо решать в границах, включающих территории активного повседневного взаимодействия.

Не менее важно определить содержательную часть пространственной стратегии крупного города. Согласно прогрессивному зарубежному опыту, стратегии пространственного развития включают общее видение города, или, как сейчас принято называть, миссию города. Это видение, во-первых, должно быть реалистичным, то есть опираться на активы города (социально-культурный потенциал, историко-культурное наследие, природное окружение, научно-производственный потенциал, географические, производственные и культурные связи); во-вторых, оно должно быть согласовано с населением, местными органами власти, бизнес-сообществом, учитывать национальные интересы. Функцию определения миссии города в настоящее время взяли на себя многие стратегии социально-экономического развития крупных российских городов, зачастую они включают и предложения по пространственной организации территории (Санкт-Петербург, Казань), но это не исключает необходимость в стратегической градостроительной документации, поскольку стратегии социально-экономического развития не содержат комплексной градостроительной концепции развития города. Миссия города раскрывается в виде блока целей, который учитывает индивидуальные особенности города и также включает стандартный набор современных целей: устойчивый город, комфортный для проживающего и временно прибывающего населения, с экологически благоприятной средой, способствующей формированию здорового поколения, конкурентоспособной экономикой. Устойчивый город в современном понимании означает, прежде всего, бережное отношение к ресурсам и возможность сохранения жизнедеятельности для будущих поколений. Кроме того, стратегия города должна учитывать современные вызовы, прежде всего, развитие процессов глобализации (при глобальной конкуренции необходимы формирование города, привлекательного для инвестиций и квалифицированных трудовых ресурсов, идентификация города в условиях глобальной стандартизации городского строительства), последствия изменения климата.

Пространственное планирование - междисциплинарная деятельность, направленная на формирование скоординированного подхода к организации пространства. Стратегический план должен учитывать политику, формируемую в разных сферах деятельности (экономической, социальной, экологи- 
ческой, транспортной, инженерного обустройства, переработки и утилизации мусора и др.), определять и согласовывать их пространственную составляющую в рамках обеспечения предпосылок для реализации миссии города. Для того, чтобы стратегия была реальной, она должна иметь ресурсное обоснование, необходимо осуществлять мониторинг её реализации по ключевым показателям, обозначенным в стратегии.

Для обеспечения социальной обоснованности и социальной направленности стратегии необходим контакт с населением не только по результатам завершения стратегического плана, но и в процессе его разработки. Задачей стратегии является определение мест развития и интенсификации с целью предоставления земли для городского строительства в нужном месте, в нужное время и в нужном количестве. Это не должно осуществляться с ущербом для качества городской среды. Следует отметить, что реализации эффективной стратегии пространственного развития возможна при наличии социально и экологически ориентированной государственной и региональной политики.

В качестве примера реализации такого подхода можно привести современный опыт Англии. Англия является наиболее продвинутой страной в области стратегического планирования. Голландия, определяя направления развития своей системы стратегического планирования, тщательно изучила и проанализировала английский опыт. Прежде несколько слов о системе пространственного планирования Англии. Система пространственного планирования в Англии претерпела существенные изменения в 2010 году [3]. До 2010 года было три уровня планирования:

- национальный уровень - Заявление о пространственной политике и принципах в отношении пространственной организации определённых сфер деятельности: планирования жилья, исторической среды, городских центров, инфраструктуры, обеспечения устойчивого развития, управления отходами и др.;

- региональный уровень - региональные стратегии (RSS);

- местный уровень - Основы местного планирования [LDF]: набор документов, который местные органы планирования - округа, районы, унитарные образования - должны создавать для описания своей стратегии развития и использования земель в рамках своей компетенции. Унитарные образования возникли в результате административно реформы в Англии в 2000-х годах путём выделения из графств городов с прилегающими территориями [4].

В 2011 году вышел «Закон о локализации» [5], отменивший региональные стратегии и сделавший акцент на местные планы. Правительство Англии стремится, чтобы каждый район имел свой местный план. В марте 2011 года Комитет общин и местного самоуправления опубликовал свой доклад о последствиях отмены регионального уровня, в котором отмечается, что «намеренная отмена региональных стратегий пространственного планирования оставляет вакуум в основе английской системы планирования, который на долгие годы может иметь глубокие социальные, экономические и экологические последствия» [6]. Это объясняется тем, что политика местного правительства всё больше зависит от проблем сообщества, в то время как политика национального правительства всё больше зависит от международной ситуации (особенно в ЕС). При этом важную роль выполняет региональный уровень как посреднический, позволяющий согласовать государственные и местные интересы.

Тем не менее в настоящее время в Англии существуют два уровня территориального планирования: национальный - Основы национальной пространственной политики (NPPF), и местный уровень - локальные планы округов, районов, общин. Локальный (местный) план устанавливает политику местного планирования и определяет, как используется земля, что и где будет построено. Мнения местных жителей имеют жизненно важное значение для формирования местного плана, помогая определить, как развивается их сообщество. Развитие должно соответствовать национальной политике планирования, плану Лондона и учитывать местные особенности. План Большого Лондона, который, по существу, является региональным, представляет исключение. Для того чтобы проиллюстрировать подход к градостроительному планированию крупного города и разработке локального (по сути генерального) плана, рассмотрим два плана: стратегический план Лондона и локальный план Лондонского сити.

\section{Стратегический план Лондона (План Лондона)}

Система пространственного планирования Большого Лондона привязана к двум уровням местного самоуправления: общегородскому, ответственному за стратегическое планирование и координируемому администрацией Большого Лондона (Great London Authority), и местному уровню (представленному 32-мя местными органами власти по числу округов и Корпора-цией Лондонского (ити), ответственному за разработку местных планов. В состав Администрации Большого Лондона входит мэр и Лондонская Ассамблея. В 1998 году на референдуме, проведённом среди жителей Лондона, было принято решение о создании единого представительного органа - Лондонской Ассамблеи (Great London Assembly - GLA), полномочия которой практически совпадали с полномочиями существовавшего ранее Совета Большого Лондона [7]. В каждом округе Лондона есть свой совет, состоящий из представителей политических партий и организаций, выбираемых каждые четыре года местными жителями. Разработка стратегического плана Лондона входит в обязанность мэра города. В соответствии с Законом о создании администрации Большого Лондона (GLA) [6] мэр города должен разработать стратегию пространственного развития (SDS), известную как «Лондонский план».

«Лондон 2018» - третий план [8], предыдущие два были подготовлены в 2004 и 2011 годах. Причиной не корректировки, а полной замены предыдущего плана явились изменения экономической ситуации, тенденции изменения климата, новые цели и задачи развития региона. План начал разраба- 
тываться в 2016-2017 годах: «Город для всех лондонцев» [9], затем, после учёта замечаний, в 2018 году вышла обновлённая версия - «План Лондона». Новый план включает многие предложения и в целом политику, на которой базировалось издание 2016 года, но имеет ряд отличий. Во вступительной части нового плана мэр города Садик Хан отмечает следующие принципиальные различия: «В отличие от предыдущих версий Лондонского плана, которые часто читаются как широкие заявления о честолюбии, а не конкретные планы действий, этот документ уделяет особое внимание осязаемой политике и вопросам планирования и обеспечивает большую ясность относительно того, как план будет осуществляться и где в Лондоне должно происходить основное развитие. Важно отметить, что план также подробно описывает, как будут взаимосвязаны регламентированные подходы в области жилья, социальной, экономической, культурной сферах, экологии, транспортной и инженерной инфраструктуры». По мнению мэра, именно «интеграция в различных областях политики является ключом к созданию условий для устойчивого роста, порождая новые и интересные возможности для лондонцев». В новом плане содержится раздел по финансированию, включающий оценку ресурсов, необходимых для реализации плана. При этом отмечается, что средств, выделяемых в настоящее время, недостаточно и описываются пути поиска недостающих средств.

Поскольку для нас наибольший интерес представляют не уточнённые цифровые показатели, а методический подход, в данном исследовании анализируются материалы обеих версий плана Лондона. Содержательная часть обеих версий плана представляет набор пространственно согласованных стратегий в разных сферах жизнедеятельности и функционально-планировочной организации территории (жильё, социальная инфраструктура, экономика, транспортная инфраструктура, зелёная инфраструктура, историко-культурное наследие, формирование центров, финансирование, мони-

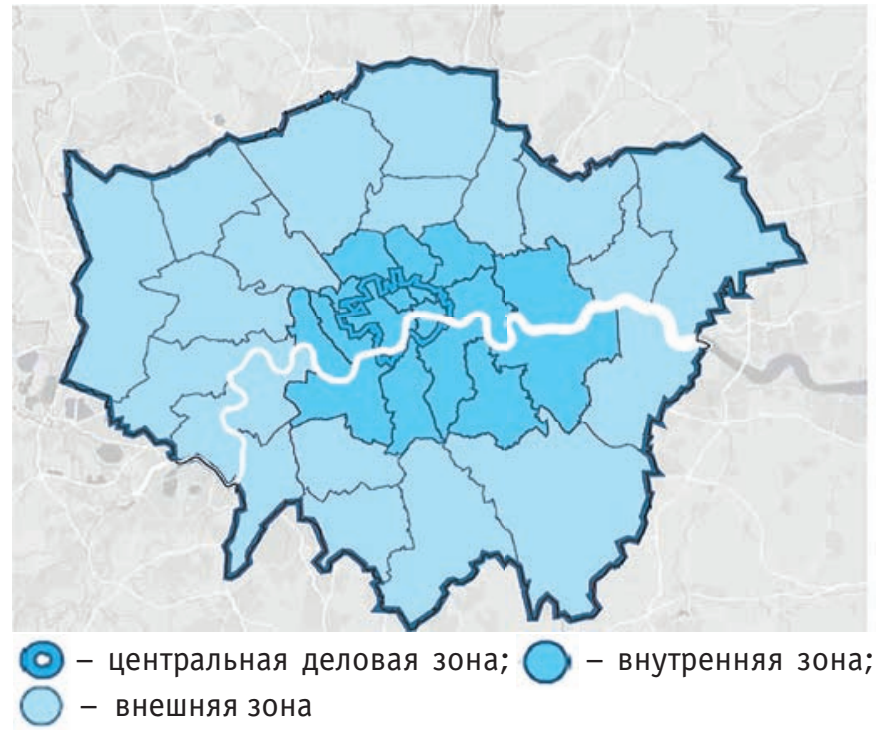

Рис. 1. Территория Большого Лондона торинг и др. Основные положения плана иллюстрируются картами-схемами, которые не являются точным отображением местоположения проектируемых объектов, но дают общее представление о пространственной политике.

Территория Большого Лондона - 1706,8 кв. км, население - 8 млн жителей (рис. 1). Миссия города определена следующим образом: «международный конкурентоспособный и успешный город с сильной и разнообразной экономикой и предпринимательским духом, который находится на переднем крае инноваций и исследований, становится мировым лидером в улучшении окружающей среды на местном уровне и во всём мире, принимая на себя ведущую роль в борьбе с изменением климата, сокращением загрязнения, развитием низкоуглеродной экономики, меньшим потреблением ресурсов и использованием их более эффективно. Город, в котором все чувствуют себя комфортно и каждому легко получить доступ к работе». Эти амбиции подкреплены развитым научным, производственным, социально-культурным потенциалом города. Лондон наряду с Нью-Йорком оценивается как главный финансовый центр в мире. Лондонские высшие учебные и исследовательские учреждения имеют мировой уровень.

Согласно законодательству, Лондонский план должен учитывать три сквозные темы:

1) экономическое развитие и создание богатства;

2) социальное развитие;

3) улучшение окружающей среды.

Разработке плана Большого Лондона предшествовали публикации мэром официальных стратегий в области транспорта (TS), неравенства в отношении здоровья (HIS), окружающей среды (ES) и жилищного строительства (HS) Он также выпустил окончательный вариант Руководства по дополнительному планированию доступного жилья, своё видение экономики ночной жизни города и видение развития туризма в Лондоне. Мэр также объявил об инвестициях и выделении средств для увеличения предложений доступного жилья в столице.

Для Лондонского плана был подготовлен дифференцированный по районам прогноз численности населения. Ожидаемый средний ежегодный прирост населения - 70000 чел., к 2041 году население достигнет 10,5 млн человек. Подготовлен также прогноз ожидаемых изменений в экономике, количественно оценено снижение числа занятых в производстве, транспорте, государственном управлении, коммунальных услугах и др., в то же время ожидается рост числа занятых в научно-технической, финансовой сферах, В гостиничной отрасли, здравоохранении, образовании. В пространственном плане наибольший рост числа занятых ожидается в центральных и внутренних районах Лондона, где концентрируются бизнес услуги.

В плане констатируется, что уровень бедности не снизился, несмотря на наблюдаемый в течение 20 лет рост экономики. Поэтому в плане есть карта дифференциации территории по уровню обездоленности населения (включая здоровье населения, доход, качество жилища, качество среды) и уде- 
ляется много внимания решению этой проблемы, в том числе пространственными средствами. Например, первоочередной реновации подлежат районы, где по комплексу факторов живут наиболее обездоленные слои населения, устанавливается процент доступного жилья (с низкой арендной платой) от общего объёма вводимого фонда.

Стратегия пространственного развития направлена на компактное развитие города за счёт выделения мест возможной интенсификации застройки территорий реновации, свободных территорий на юго-востоке, подлежащих освоению.

Пространственная политика основана на полицентризме с целью снижения центростремительных тенденций и приближения населения к центрам разного уровня.

В стратегии применяется подход, называемый «формирование места», в основе которого лежит смешанное функциональное использование территории, подчёркивание местных особенностей, высокое качество городской среды.

Интегрированная пространственная политика отражена на ключевой карте-схеме (рис. 3)

Большое внимание уделяется мероприятиям по улучшению экологической ситуации (низкоуглеродная экономика, увеличение озеленённых пространств, снижение поездок на индивидуальном транспорте, электрифицированный транспорт и др.) Выделяются фокусные экологически проблемные территории по двум критериям: уровень загрязнения и количество населения, проживающего на особо загрязнённых территориях.

Определена политика в отношении утилизации мусора, рассчитаны ожидаемые объёмы выброса, в том числе наиболее опасного, необходимое увеличение мощностей хранения и переработки мусора. Приоритетной задачей плана является защита территории от неблагоприятных последствий изменения климата. Ожидается, что к 2050 году средняя температура увеличится на 2,7 градуса, повысится вероятность затопления территории, на которой проживает 1,5 млн жителей и находится

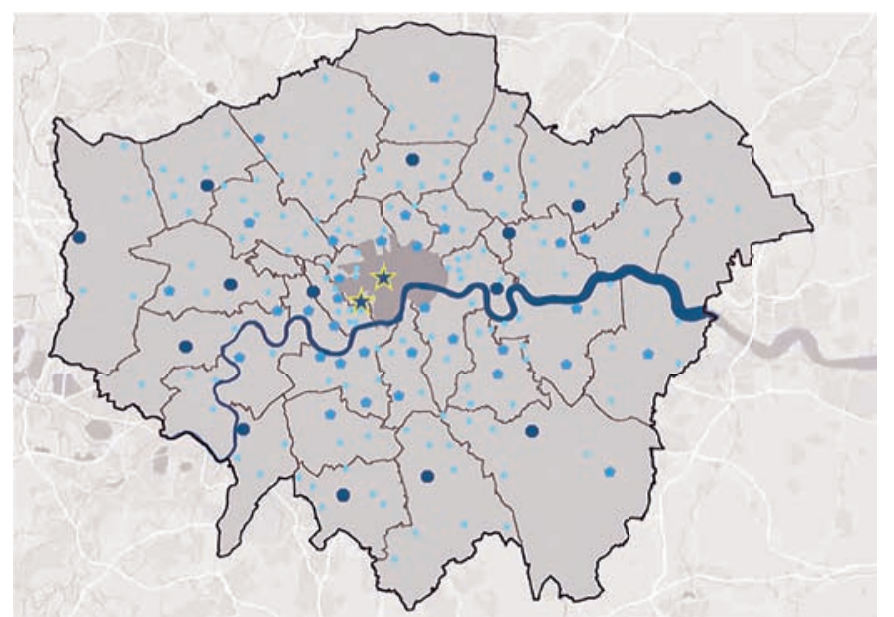

$\star$ - международный центр; $\bigcirc$ - столичный центр;

- крупный центр; - районный центр;

тральная деловая зона

Pис. 2. Структура городских центров
480000 объектов недвижимости, будет остро ощущаться нехватка воды (особенно на юго-востоке). Содержится раздел по финансированию и мониторингу реализации плана.

\section{Лондон. Городской план-2036}

План Большого Лондона является основанием для разработки локальных планов 32-х крупных городских административных районов и Лондонского Сити. К 2020 году городской корпорацией должна быть завершена разработка локального плана Лондонского Сити на период до 2036 года. Нынешний план был разработан в 2015 году, необходимость в новом плане была вызвана изменениями в политике, экономике, а также публикацией нового плана Большого Лондона. Местный план учитывает национальную и лондонскую политику, руководство по планированию, а также планы и стратегии, разработанные соседними районами [10].

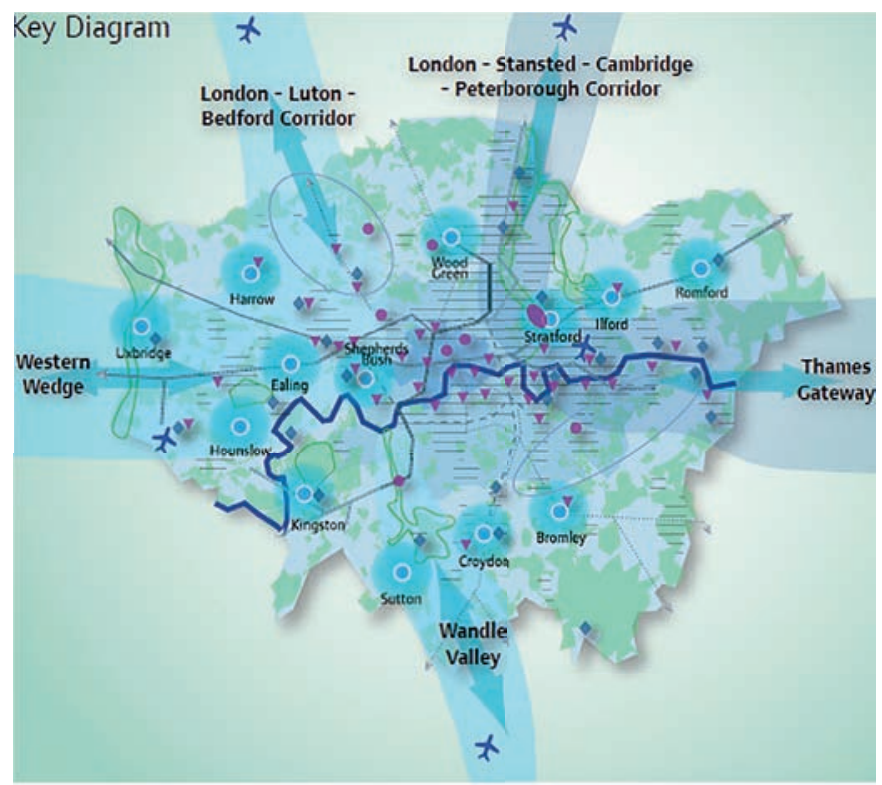

- центральная зона активности; - внутренняя территория Лондона; - внешняя территория Лондона; ○ - столичные центры; - территории, имеющие возможности для развития; - территории интенсификации; - стратегические центры развития за пределами Лондона; - территории LLDC (The London Legacy Development Corporation) - Лондонская корпорация развития наследия; || - территории регенерации; ○ - региональные парки; - территории для возможной организации региональных парков; - зелёный пояс, открытые пространства; - региональные координируемые коридоры;

- национальные развивающиеся территории; * - главные аэропорты; | - пересекающая железная дорога 1; | - пересекающая линия метро 2; | - пересекающая железная дорога регионального значения; | - скоростная магистраль; -Темза; - Лондонские надземные линии

Рис. 3. Ключевая карта-схема 
Лондонский Сити - административно-территориальное образование со статусом «сити», церемониальное графство в центре региона Большой Лондон, историческое ядро Лондона, сформировавшееся на основе древнеримского города Лондиниум, его площадь составляет - 314,96 га.

Постоянное население города, которое, по оценкам, составляет около 7400 человек, невелико по сравнению с ежедневным рабочим населением, превышающим 480000 человек. Согласно прогнозам, население города (исключая тех, у кого есть основные дома в других местах, перепись 2011 года показала, что в Лондонском Сити было 1400 вторых домов) к 2036 году ожидается увеличение численности населения до 10000 человек.

Технологии разработки плана включают шесть этапов:

1) консультация с общинами по ключевым вопросам, связанным с появляющимися вариантами - 2016 год;

2) разработка плана и выпуск для рассмотрения общественностью - 2018-2019 годы;

3) публикация плана для окончательной консультации с общественностью - 2019 год;

4) представление стратегии государственному секретарю, который назначает инспектора - 2019-2020 годы;

5) инспектор рассматривает план и представляет на общественную сессию, чтобы услышать подтверждение по ключевым вопросам;

6) одобрение. Рекомендации инспектора рассматриваются городской корпорацией и потом план получает одобрение 2020 год.

Прежде чем представить план города 2036 года государственному секретарю, городская корпорация, ответственная за разработку плана, продемонстрирует возможность реализации инфраструктуры в течение планового периода.

Городской план разработан одновременно с транспортной стратегией и рассматривается совместно с ней, правда сроки разработки документов разные: местный план - до 2036 года, транспортная стратегия - до 2043 года. Это связано с тем, что сроки разработки местного плана предписаны в Правилах. Проект местного плана поддерживает амбициозное видение города в ближайшие двадцать лет: привлекательный, динамичный, инклюзивный, безопасный, с инновационной экономикой, высоким качеством городской среды. Пространственная стратегия Сити предусматривает интенсификацию использования территории не за счёт сокращения открытых пространств, которые увеличиваются с ростом населения, а за счёт высотного офисного строительства. План содержит набор регламентированных подходов по самым разным вопросам и пространственные аспекты их реализации. В плане даны следующие основные рекомендации по развитию города: увеличение офисных площадей для развития малых и средних предприятий, создание современной инновационной инфраструктуры - инкубаторов, стартапов.

Лондонский Сити - ведущий мировой центр финансовых услуг, играет важную в национальном масштабе роль в экономике. Для сохранения этой позиции жизненно важно обеспечить достаточное количество территорий для качественного офисного пространства. Общая целевая площадь офисных площадей составляет 2000000 кв. м и определяется на основе предполагаемого роста числа занятых в офисах в период с 2016-го по 2036 год. В плане предусмотрено смешанное зонирование, офисные помещения будут дополняться другими коммерческими, культурными и розничными учреждениями, предусмотрены развитие зелёной инфраструктуры, в том числе за счёт озеленения жилых и общественных зданий, приоритетное выделение пространств для пешеходов, защита от неблагоприятных последствий изменяющегося климата, выделение территорий для жилищного строительства [не менее 146 жилых помещений в год, в число которых входит доступное жилье (в основном арендное жилье по низкой плате). Большинство новых жилых комплексов планируется размещать вблизи существующих жилых районов. Жилищная кластеризация уменьшает потенциальный конфликт с коммерческими и офисными зданиями, позволяет легче организовать обслуживание и обеспечить высокое качество жилой среды. Учтена потребность в учреждениях розничной торговли и определены места их предпочтительного размещения. Большое внимание уделяется повышению привлекательности территории для туристов. По оценкам, ежегодно в город приезжает около 18 млн бизнесменов и туристов, и ожидается, что их количество будет продолжать расти в результате увеличения предложений по культурным объектам и улучшения транспортной доступности. С учётом посетителей рассчитывается необходимое количество мест разного качества в отелях. Предусмотрена защита исторических и археологических памятников, определены места консервации объектов. Предусмотрены меры по улучшению биоразнообразия - создание мест обитания для воробьёв, сапсанов, стрижей и др., и расширение круга насекомых и птиц.

В отношении мест утилизации отходов соблюдается принцип близости, чтобы уменьшить воздействие их транспортировки на окружающую среду. Правда, в связи с ограниченностью территории в Сити, необходимые места ищут в прилегающих районах. Технологическая политика направлена на развитие цикличной экономики с целью сокращения отходов. План включает карты, иллюстрирующие пространственную политику города: размещение образовательных, 03доровительных, культурных торговых учреждений, гостиниц, туристических достопримечательностей, жилых территорий. высотных зданий. Транспортный раздел содержит железнодорожную и подземную инфраструктуру, классификацию улиц, ключевые пешеходные маршруты, велосипедную сеть дорог. Показаны открытые пространства, историко-культурные памятники и зоны их восприятия, территории, подверженные риску затопления, направления вывоза мусора и схемы семи зон ключевых изменений.

В качестве дополнительного документа был принят Исполнительный план городской корпорации, содержащий стандарты и целевые показатели, а также процедуры, ко- 
торые будут применяться для обеспечения эффективного регулирования развития. План исполнения будет постоянно пересматриваться и дополняться, чтобы отражать меняющуюся ситуацию. Проект Плана города-2036 был основан на Комплексной оценке воздействия (IIA), которая объединяет следующие процессы оценки в единый документ:

- оценка устойчивости, включая стратегическую экологическую оценку;

- оценка воздействия на равенство возможностей людей с разными доходами;

- оценка воздействия на здоровье.

Ключевым механизмом реализации местного плана является рассмотрение заявок на строительство на предмет соответствия их плану.

Реализация нового местного плана, когда он будет принят, потребует партнёрских отношений и сотрудничества с целым рядом организаций, включая застройщиков, бизнесменов, жителей, общественные организации, поставщиков транспортных услуг, мэров Лондона и соседних районов. Если средств на реализацию планируемой инфраструктуры окажется недостаточно, городская корпорация будет изыскивать дополнительные источники финансирования.

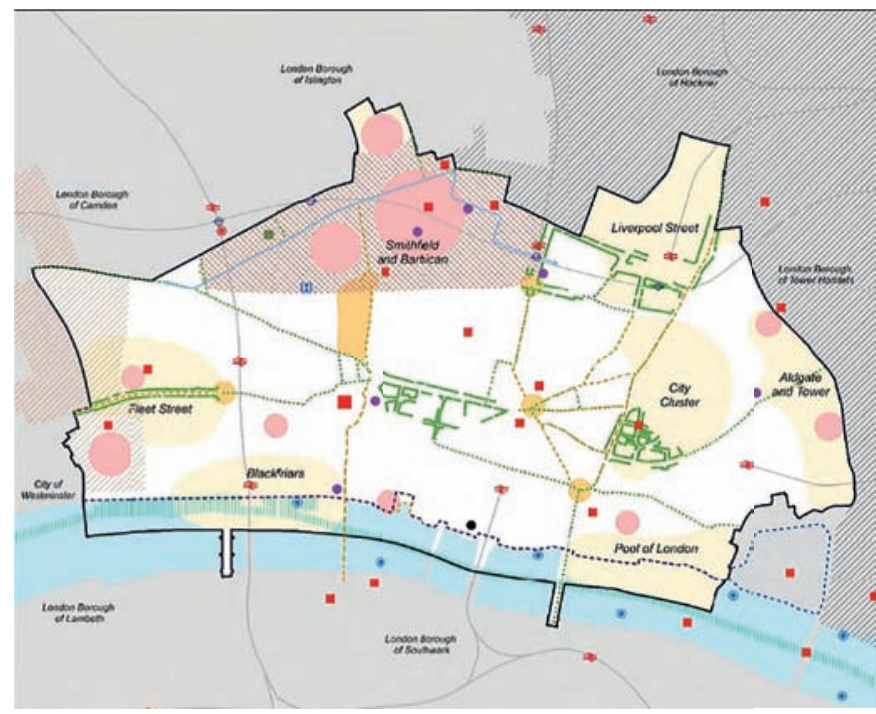

$\square$ - границы сити Лондона; —- - главная линия железной дороги; * - железнодорожная станция; $\odot-$ линия Элизабет; (- река Паер; --.- - прибрежный парк и прогулочная дорога; - улучшенные связи; - у- - улучшение маршрута;

- ключевые территории изменений; - жилые массивы; - главные торговые центры; ....... - торговые линии; $\rightleftarrows$ - развитие культуры; ши - тоннель Темзы; ;....; - места мирового наследия; Ша - территории технических возможностей; - планируемый правовой кластер; - культурная миля; - кафедральный собор Святого Павла; =- ключевые места привлечения посетителей; = - кузнечный рынок; - - ТЭЦ; в - больница Святого Варфоломея; - - образовательные учреждения

Рис. 4. План ключевой области изменений
На рисунке 4 показан пример планирования ключевой области изменений. На востоке города самая высокая плотность деловой активности. Там находятся высокие здания, предусмотренные под офисы в сфере банковского и страхового использования и широкого спектра технологических, юридических и деловых услуг

***

В заключении следует отметить, что при анализе зарубежного опыта необходимо учитывать несовершенство существующего терминологического аппарата. Термины «стратегический план», «мастер-план», «генеральный план», «региональный план» часто используются как взаимозаменяемые. Например, план Большого Лондона трактуется как стратегический план, в тексте присутствует название региональный план, план развития региона Париж/Иль-деФранс обозначен как генеральный план развития региона Парижа, в статьях, посвящённых проекту, используется термин «региональный проект». Вместе с тем можно проследить разницу между стратегическим и генеральным планом. Стратегический план - концептуальный документ, определяющий обоснованное видение будущего крупного города совместно с прилегающими, тесно взаимодействующими с

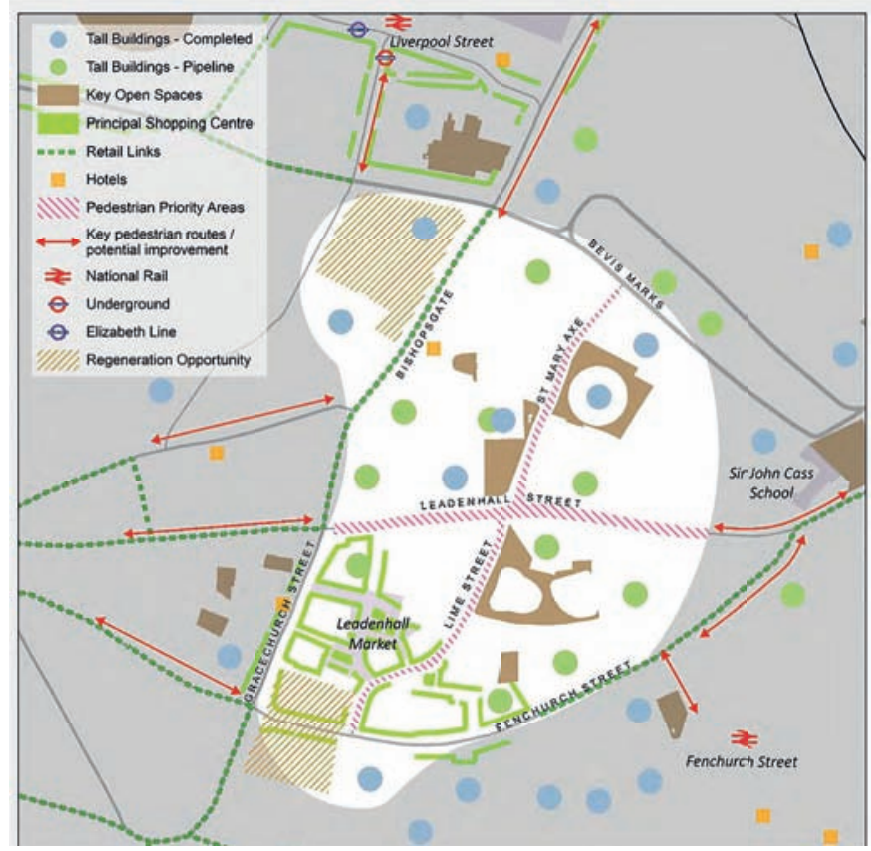

- построенные высотные здания; - планируемые высотные здания; - ключевые открытые пространства;

- главные торговые центры; ".... - торговые связи;

- отели; $\longleftrightarrow-$ ключевые пешеходные маршруты; $\approx-$ национальная железная дорога; $\ominus$ - метро; $\theta-$ линия Элизабет; चाи - возможность регенерации

Рис. 5. Кластер города. Ключевая область изменений 
ним территориями, стратегические цели и направления их достижения. Стратегический план является основанием для планирования распределения ресурсов с целью реализации стратегических целей. Генеральный план должен базироваться на информации, полученной от стратегического плана, конкретизируя планировочные мероприятия в рамках определённой стратегии. В этом смысле генеральный план является уточнённым детализированным фрагментом стратегического плана. Это подтверждает приведённый выше опыт разработки стратегического плана Большого Лондона и локального (генерального плана) фрагмента его территории - Сити Лондона. Россия также имеет аналогичный опыт двухстадийного проектирования крупного города: ТЭО на территорию города и пригородной зоны и генерального плана. Однако по содержанию ТЭО существенно отличается от современных стратегий. Часто генеральный план подменяется термином «мастер-план», но это не всегда одно и то же. В большинстве случаев мастер-план сочетает элементы стратегических и генеральных планов (видение будущего города, согласованное с населением, властями, бизнес-сообществом, стратегические цели и конкретные мероприятия по их достижению). В отличие от стратегического плана крупного города объектом мастер-плана является в большинстве случаев только город. Опираясь на прошлый российский и современный зарубежный опыт, можно сделать вывод о целесообразности разработки для крупного города стратегии пространственного развития. Её основная цель - не ускорить градостроительное обеспечение строительства, а способствовать формированию успешного комфортного, привлекательного для инвестиций и жителей города. Разработка этого плана требует применения современных технологий, которые используются не только в Англии, но в других развитых странах. Они включают рассмотрение крупного города во взаимосвязи с прилегающими территориями, определение видения будущего города, которое должно быть подкреплено активами города, имеющимися ресурсами и ресурсами, которые реально привлечь. Стратегический план по сути - это набор мотивированных, реальных подходов, пространственно согласованных, направленных на реализацию видения будущего города, отвечающих на главные вызовы современности. Этот план должен дисциплинировать строительный комплекс и управлять им, а не идти на поводу. Стратегический план согласовывает стратегии пространственного развития различных сфер деятельности в рамках общей политики реализации видения будущего города и учёта современных вызовов. Необходимой предпосылкой реализации эффективных планов является наличие государственной социально и экологи-чески ориентированной политики.

Если не формально отнестись к поручению президента, необходимо комплексно решать поставленную задачу, меняя не только форму, но, главное, содержание стратегического плана города. Необходимо использование современных методов разработки и управления реализацией плана. На по- ставленный вопрос «быть или не быть генеральным планам?» можно ответить, что крупный город должен иметь стратегический план на территорию города и прилегающую зону и генеральные планы на отдельные крупные административнотерриториальные образования в его составе, разработанные с использованием современных прогрессивных технологий.

\section{Лuтература}

1. Об обеспечении выполнения поручения Президента России по итогам расширенного заседания президиума Госсовета 23 ноября 2018 года [Электронный ресурс] // Правительство России. Официальный сайт. - Режим доступа: http://government.ru/orders/selection/404/35456/ (дата обращения 05.03. 2019).

2. В России для крупных городов отменят генеральные планы [Электронный ресурс] // Новостной портал «Известия» - IZ.RU/. - Режим доступа: http://www.1sn.ru/224485.html (дата обращения 5.03. 2019).

3. An Overview of Spatial Policy in the United Kingdom [Электронный ресурс] // An Overview of Spatial Policy in Asian and European Countries. - Режим доступа: https://www.mlit. go.jp/kokudokeikaku/international/spw/gen (дата обращения 15.01 2019).

4. Localism Act 2011 [Электронный ресурс] // Legislation. gov.uk. - Режим доступа: www.legislation.gov.uk/ ukpga/2011/20/pdfs/ukpga_20110020_en.pdf ( дата обращения:15.01 2019).

5. Лангинен, A.В. Основные результаты реформы местного государственного управления и самоуправления в Великобританиии [Электронный ресурс] / А.В. Лангинен // Научноинформационный журнал «Вопросы управления». - 2009. № 4 (9). - Режим доступа: vestnik.uapa.ru/issue/2009/04/06/ (дата обращения 2.02 2019).

6. Regional spatial strategy [Электронный ресурс] // Wikipedia. - Режим доступа: https://en.wikipedia.org/wiki/ Regional_spatial_strategy (дата обращения 25.02 2019).

7. Greater London Authority (GLA) [Электронный ресурс] // Practical Law. - Режим доступа: https://uk.practicallaw. thomsonreuters.com/5-508-0391?transitionType=Default\&co ntextData $=($ sc. Default $) \&$ firstPage $=$ true $\&$ comp $=$ pluk\&bhcp $=1$ (дата обращения 10.012019 ).

8. The London Plan - Greater London Authority [Электронный ресурс]. - Режим доступа: https://www.london.gov.uk/ sites/.../the_london_plan_malp_final_for_web_0606_0.p. (дата обращения 25.02 2019)

9. The London Plan : The spatial development strategy for London consolidated with alterations since 2011. March 2016. [PDF] London Plan - Greater London Authority. [Электронный ресурс]. - Режим доступа: https://www.london.gov.uk/sites/ default/files/new_london_plan_december_2017.pdf (дата обращения 07.012019 ).

10. City Plan 2036 Shaping the future City - City of London [Электронный ресурс]. Режим доступа: Meetings 
...democracy.cityoflondon.gov.uk/.../Appendix $\% 201 \% 20$

Draft... (дата обращения 09.02.2019)

\section{References}

1. Ob obespechenii vypolneniya porucheniya Prezidenta Rossii po itogam rasshirennogo zasedaniya prezidiuma Gossoveta 23 noyabrya 2018 goda [Elektronnyj resurs] [0n ensuring the fulfillment of the instructions of the President of Russia following the results of the enlarged meeting of the Presidium of the State Council on November 23, 2018]. Pravitel'stvo Rossii. Ofitsial'nyj sajt [Russian Government. Official site]. URL: http://government.ru/orders/selection/404/35456/ (accessed 05.03.2019).

2. V Rossii dlya krupnyh gorodov otmenyat general'nye plany [Elektronnyj resurs] [In Russia for major cities will cancel master plans]. Novostnoj portal «Izvestiya» -IZ.RU [News portal "Izvestia" - IZ.RU]. URL: http://www.1sn.ru/224485.html (accessed 5.03.2019).

3. An Overview of Spatial Policy in the United Kingdom [Elektronnyj resurs]. An Overview of Spatial Policy in Asian and European Countries. URL: https://www.mlit.go.jp/ kokudokeikaku/international/spw/gen (accessed 15.01.2019).

4. Localism Act 2011 [Elektronnyj resurs]. Legislation. gov.uk. URL: www.legislation.gov.uk/ukpga/2011/20/pdfs/ ukpga_20110020_en.pdf (accessed:15.01.2019).
5. Langinen A.V. Osnovnye rezul'taty reformy mestnogo gosudarstvennogo upravleniya i samoupravleniya $v$ Velikobritaniii [Elektronnyj resurs] [Main outcomes of the reforms of the local public administration and the local government in Great Britain]. Nauchno-informatsionnyj zhurnal «Voprosy upravleniya» [Scientific-Information Journal "Management Issues"], 2009, no. 4 (9). URL: vestnik.uapa.ru/ issue/2009/04/06/ (accessed 2.02.2019).

6. Regional spatial strategy [Elektronnyj resurs]. Wikipedia. URL: https://en.wikipedia.org/wiki/Regional_spatial_strategy (accessed 25.02.2019).

7. Greater London Authority (GLA) [Elektronnyj resurs]. Practical Law. URL: https://uk. practicallaw.thomsonreuters. com/5-508-0391?transitionType=Default\&contextData=(sc.Def ault)\&firstPage=true \&comp $=p l u k \& b h c p=1$ (accessed 10.01.2019).

8. The London Plan - Greater London Authority [Elektronnyj resurs]. URL: https://www.london.gov.uk/sites/.../the_london_ plan_malp_final_for_web_0606_0.p. (accessed 25.02.2019).

9. The London Plan : The spatial development strategy for London consolidated with alterations since 2011. March 2016. [PDF]. London Plan - Greater London Authority. [Elektronnyj resurs]. URL: https://www.london.gov.uk/sites/default/files/ new_london_plan_december_2017.pdf (accessed 07.01.2019).

10. City Plan 2036 Shaping the future City - City of London [Elektronnyj resurs]. URL: Meetings ...democracy.cityoflondon. gov.uk/.../Appendix\%201\%20Draft.. (accessed 09.02.2019).

Герцберг Лора Яковлевна (Москва). Доктор технических наук, член-корреспондент РААСН. Главный научный сотрудник ФГБУ «Центральный научно-исследовательский и проектный институт Министерства строительства и жилищно-коммунального хозяйства» (119331 , Москва, просп. Вернадского, 29. цНИИП Минстроя России). Эл.почта: lgertz24@mail.ru.

Gertsberg Lora Yakovlevna (Moscow). Doctor of technical sciences, corresponding member of the RAACS. Chief researcher of the FGBU "The Central Institute for Research and Design of the Ministry of Construction and Housing and Communal Services of the Russian Federation" (119331, Moscow, Vernadskogo ave., 29. TSNIIP Minstroy of Russia). E-mail: Lgertz24@mail.ru. 